\title{
TLUMOČENÍ Z ČESKÉHO ZNAKOVÉHO JAZYKA DO MLUVENÉ ANGLIČTINY S ČEŠTINOU JAKO PILOTNÍM JAZYKEM
}

\author{
MARIE PŘIBYLOVÁ
}

\begin{abstract}
Relay interpreting between Czech sign language and spoken English With growing emancipation of the Deaf, sign language has been making its way into conference rooms, entering in contact not only with foreign sign languages, but also with spoken ones. Logically, this entails the need for interpreting, and as the number of interpreters working directly between the national sign language and a foreign spoken language is - at least in the Czech Republic - very low, relay interpreting comes into play. Our research focuses on the quality of relay interpreting, the main criterion being content fidelity. Despite the fact that research on relay has not shown any significant deterioration in quality, we believe meaning shifts still occur, and that they will differ in languages with different modalities (visual/spatial vs. aural/oral); in the sign-to-speech combination, the primary factors are considered to be the simultaneity of expression and the necessity of processing visual input.

An experiment will be conducted to test the hypothesis that if meaning shifts and information loss occur in relay interpreting, their nature will differ depending on the language combination (sign-to-speech X speechto-speech), due in particular to the different modalities of the languages involved.

The following research questions will be asked: Do meaning shifts and information loss occur during relay interpreting between languages of different modalities? If so, is relay interpreting itself a factor? If so, do meaning shifts and information loss occur in the first or second interpreting stage? Due to which factors? Is working into one's B-language a factor? Is the interpreter's experience level a factor?

The experiment will be conducted in laboratory settings, with four pairs of interpreters with various levels of experience relaying between Czech sign language and spoken English via spoken Czech. As a control, the same pattern will be used in interpreting a speech from spoken French to spoken English via spoken Czech.
\end{abstract}

Keywords: Czech sign language; relay interpreting; meaning shifts; modality; directionality in interpreting

Se stále narůstající emancipací Neslyšících se zvyšuje i počet př́ležitostí, v nichž se český znakový jazyk (ČZJ) dostává do kontaktu s cizími mluvenými jazyky, zejména 
s angličtinou. Co se České republiky týče, akce konferenčního charakteru s mezinárodní účastí, při nichž by docházelo k přímému formálnímu kontaktu mezi znakovým a mluveným jazykem, nejsou jevem příliš častým; počet kvalifikovaných tlumočníků schopných tlumočit přímo mezi ČZJ a mluvenou angličtinou je zatím velmi nízký. V prrípadě potřeby tak místo přímého tlumočení nastupuje pilotáž s mluvenou češtinou jako zprostředkujícím (pilotním) jazykem. ${ }^{1}$

Následující text shrnuje teoretická východiska pro experiment prováděný v rámci výzkumu zaměřeného právě na výše uvedenou situaci (pilotáž). Soustředuje se především na specifické lingvistické charakteristiky znakového jazyka, které dle našeho názoru ovlivňují tlumočnický proces. Klademe si otázku, zda je tento proces a jeho výsledek kvůli těmto specifikům odlišný od procesu a výsledku tlumočení mezi mluvenými jazyky, a jaký je vliv dalších proměnných.

\section{Bimodální tlumočení}

Tlumočení mezi znakovým a mluveným jazykem je z několika důvodů velmi specifické. Nejvýraznější specifikum zde představuje fakt, že jde o tlumočení mezi jazyky s odlišným způsobem existence (vizuálně-motorickým vs. audio-orálním), tedy takzvané bimodální tlumočení, které klade na tlumočníky zvláštní nároky. Napierová (2002: 17, 29) uvádí, že „tlumočení znakového jazyka se v porovnání s tlumočením jazyka mluveného vyznačuje specifickými rysy“a že „tlumočníci znakového jazyka jsou konfrontování s mnoha problémy, které se liší od problémů, jimž čelí tlumočníci mluveného jazyka“2

Patrně nejvýraznějším rysem způsobu existence znakového jazyka je přenos vizuálním kanálem, a tlumočníci tak slovy Napierové (2002: 35) „neustále převádějí informace mezi dvěma různými modalitami, což vyžaduje vyjadřování informací velmi odlišnými způsoby“. „Odlišnými způsoby“ se rozumí především zpơsob řazení jednotek od úrovně fonematické po textovou, kdy jazyk mluvený uspořádává své jednotky převážně lineárně, a to zejména $\mathrm{z}$ toho důvodu, že audioorálním kanálem lze většinou produkovat i vnímat vždy pouze jednu jednotku, zatímco znakový jazyk, řečeno se Slánskou Bímovou a Okrouhlíkovou (2008: 60), „své jednotky uspořádává primárně simultánně“. To je umožněno využíváním obou rukou, pohybu horní části těla a mimiky, to vše v trojrozměrném prostoru. Znakový jazyk je tak schopen souběžného vyjádření několika konceptů zároveň, a to jednak na úrovni samotného znaku, jednak na úrovni syntaktické, kdy je možné produkovat více znaků zároveň a různě je kombinovat. Ačkoli i mluvený jazyk simultánní vyjádření do jisté míry umožňuje, zejména prostřednictvím gramatických afixů

1 Pokud jde o znakový jazyk, tlumočení s pilotáží se využívá především v př́ípadě kontaktu mezi několika cizími znakovými jazyky, př́p. mezinárodním znakovým systémem, nebo $\mathrm{v}$ př́padech, kdy jeden neslyšící používá variantu znakového jazyka, která je slyšícímu tlumočníkovi nedostatečně srozumitelná (dialekt, omezené komunikační schopnosti účastníka, nedůvěra vǔči slyšícímu účastníkovi komunikace); v takových případech zastává roli pilotního tlumočníka neslyšící tlumočník, který převádí projev ve znakovém jazyce do standardní formy srozumitelné slyšícímu tlumočníkovi tlumočícímu do mluveného jazyka.

2 Není-li uvedeno jinak, citace cizojazyčných autorů jsou uváděny ve vlastním překladu autorky tohoto textu. 
(například čeština dokáže jednou pádovou či slovesnou koncovkou vyjádřit mluvnický rod, osobu a číslo), jsou tyto možnosti ve znakovém jazyce neporovnatelně širší. Znak, základní jednotka znakového jazyka, je charakterizován čtyřmi hlavními parametry, jimiž jsou tvar ruky, její umístění v prostoru a pohyb, orientace ruky vůči tělu. Uváděné parametry znaku jsou nejen významotvorné z obsahového hlediska, nýbrž vyjadřují i gramatické kategorie. Protože jsou tyto parametry vyjadřovány rukama, označují se jako manuální složky znaku. Kromě nich se vyskytují i složky nemanuální, které jsou vyjadřovány jinými prostředky (pozice a pohyb horní poloviny těla a hlavy a zejména mimika a pohyby úst). Manuální i nemanuální složky znaku jsou tedy nositeli gramatického významu, slouží k vyjádření otázky, rozkazu, aktuálního členění větného, různých typů vedlejších vět a podobně.

Simultánní povaha znakového jazyka z jistého hlediska umožňuje formální úspornost vyjádření. Kde je v mluvené češtině nutno několik větných členů řazených lineárně za sebou, produkuje mluvčí znakového jazyka příslušný tvar ruky, pohyb a mimické prostředky, to vše zároveň.

Jestliže platí, že „simultánně-prostorová organizace jde napříč všemi rovinami stavby znakového jazyka; na všech se uplatňují a všechny navzájem propojují procesy, které jsou výrazně odlišné od ,našich ', ,známých ', srozumitelných “"3, lze předpokládat, že výše uvedené rysy znakového jazyka budou proces i výsledek převodu mezi ČZJ a mluvenou češtinou ovlivňovat, přičemž kromě odlišných lingvistických charakteristik považujeme za relevantní i čistě kognitivní aspekty bimodálnosti, konkrétně recepci a zpracování vizuálně přijaté informace v porovnání s informací přijatou zvukovým kanálem.

\section{Recepce vizuální informace}

Řeč je kontinuální signál. Jak uvádí Schermerová a Pfau (2016: 32), „mluvčí určitého jazyka dokážou bez větších potíží rozeznat v proudu zvuku smysluplné zvuky, pokud tyto zvuky patři do repertoáru jejich jazyka“"4 Tvrzení o rozpoznávání smysluplných prvků v proudu řeči lze analogicky aplikovat i na znakový jazyk a na rozeznání vizuálního vstupu.

Jak pro jazyky mluvené, tak jazyky znakové zároveň platí, že „mluvčí, pro něž je tento jazyk cizím jazykem, mohou mít v tomto ohledu problémy “. ${ }^{5}$ Nabízí se tedy otázka, zda a jak tyto potenciální problémy ve fázi recepce ovlivňují výkon tlumočníka a výsledný projev. Skutečnost, že provést pohyb trvá déle než vyprodukovat zvuk, by mohla budit dojem, že produkce znakového jazyka je pomalejší a jeho vnímání tedy jednodušší. Na druhou stranu však podle Slánské Bímové a Okrouhlíkové (2008: 57) je tato vlastnost kompenzována právě výše uvedenou simultánností. K ní dále přispívá fakt, že „vizuální

\footnotetext{
Macurová (2011: 96) v Hynková Dingová (2017: 240).

Schermer - Pfau (2016: 32).

Ibid., s. 33-34. Domníváme se, že pro nerodilé mluvčí znakového jazyka, jejichž mateřským jazykem je jazyk mluvený, je podobné rozlišování ještě obtížnější, a to z důvodů, jimiž se zabýváme dále v textu.
} 
kanál přenese za stejný časový úsek mnohem více informací než kanál sluchový“", přičemž jen minimum informací přenesených vizuálně je jazykově relevantní. Na druhou stranu uvádějí Schermerová a Pfau (2016: 34), že „vizuální percepční systém je mnohem lépe uzpůsoben zpracovávání simultánního vstupu než systém sluchový. Proto je zpracovávání různých zdrojů vizuální informace méně složité, než by bylo možno očekávat."

Dle Llewellyn-Jonesova modelu fungování pracovní paměti vycházejícího z Baddeleyho $(1979)^{7}$ funguje ve fázi recepce takzvaná artikulační smyčka (nazývaná též „fonologická“8), díky níž je informace v pracovní paměti uchována po maximální dobu cca 4,5 sekund a z níž lze zachycenou informaci znovu vyvolat. Je nasnadě, že obdobný systém uchování informace existuje i u osob neslyšících, respektive u osob používajících znakový jazyk. Schermerová a Pfau (2016: 36) uvádějí, že „existence repetitivní smyčky ve vizuálně-prostorové části pracovní paměti, tedy smyčky vizuálně-prostorové, je velmi pravděpodobná“. $Z$ toho vyplývá, že proces ukládání informace do krátkodobé (pracovní) paměti je u slyšících a neslyšících osob pravděpodobně obdobný, bez ohledu na typ vstupního kanálu.

Z výše uvedeného vyplývá, že vyšši obtížnost zpracování vizuálního vstupu v porovnání se zvukovým vstupem není zcela jednoznačná. Otázkou však zůstává, jaké nároky klade zpracování vizuálně vyjádřené informace na př́iemce, který je rodilým mluvčím jazyka audioorálního způsobu existence. Domníváme se, že tyto nároky jsou na takového př́ijemce vyšší než v prŕpadě zpracování informace přenášené sluchovým kanálem. $\mathrm{Na}$ základě toho je možné se domnívat, že s úrovní znalosti znakového jazyka a délkou praxe jeho užívání se tyto nároky snižují, a mají-li tyto nároky vliv na kvalitu tlumočení, pak se lze domnívat, že s praxí se tato kvalita zvyšuje.

\section{Tlumočení s pilotáží (relay)}

V př́padě potřeby tlumočení mezi českým znakovým jazykem a mluvenou angličtinou je možné nedostatek tlumočníků schopných zajistit přímé tlumočením vyřešit tlumočením s pilotáží - nepř́mým, dvoufázovým neboli dvoustupňovým tlumočením, jež Pöchhacker (2004: 21) definuje jako „neprímé tlumočení prostřednictvím třetího jazyka, které spojuje projev dvou (nebo více) tlumočníků, přičemž projev jednoho tlumočníka slouží jako zdroj ostatním tlumočníkům“. Podle Mikkelsonové (1999: 4) je nezbytné tehdy, když „jsou v tlumočené situaci používány více než dva jazyky a není $\mathrm{k}$ dispozici jeden tlumočník, který by je ovládal všechny, nebo není $\mathrm{k}$ dispozici tlumočník $\mathrm{s}$ danou jazykovou kombinacíc.

Výzkumů o pilotáži nebylo provedeno mnoho. K dispozici jsou zejména teoretické statě zabývající se problematikou pilotáže obecně. Pilotáž je kvůli své specifické povaze námětem značného počtu didaktických prací a doporučení pro pedagogickou i tlumočnickou praxi. Seleskovitchová a Ledererová (1995) vypracovaly přehled zásad pro tlumočení s pomocí pilotáže doplněný o doporučení pro její výuku; zaměřují se přitom na všechny aspekty formy i obsahu, zejména volbou pilota v závislosti na jeho jazyko-

\footnotetext{
Slánská Bímová - Okrouhlíková (2008: 57).

V Llewellyn-Jones (2015: 136).

Schermer - Pfau (2016: 35)
} 
vých kompetencích, jeho ideálním profilem, organizací jednání i volbou vhodné jazykové kombinace a direkcionalitou. Zásadami správné pilotáže v konferenčním prostředí se zabývá i Jones (2002), který se kromě jednoznačnosti obsahu a srozumitelnosti vyjádření z hlediska artikulace i stylu zaměřuje také na psychologii pilotáže a praktické (organizační) záležitosti. Na výše uvedené aspekty pilotáže se soustředila také Čeňková (2015).

V souvislosti s komunitním tlumočením se pilotáži věnuje Mikkelsonová (1999).

Pokud jde o (empirické) výzkumné práce, ve své nepublikované diplomové práci se tímto tématem zabývala již v roce 1983 Jennifer Mackintoshová na University of London (viz níže).

Seleskovitchová a Ledererová (1995: 185) zmiňují průzkum z roku 1985, v jehož rámci zjištoval Fleming (SCIC) postoj tlumočníků k pilotáži, konkrétně k aspektům formy i obsahu projevu pilotního tlumočníka.

V českém prostředí (na ÚTRL FF UK) vznikly na téma pilotáže dvě diplomové práce - Jarolím (1999) se za pomoci experimentu snažil vyhodnotit, zda ztráta informace, kterou považuje u tlumočení s pilotáží za výraznější než u přímého tlumočení, brání efektivní komunikaci, a zjistit, ve které fázi dochází k většímu množství posunů. Kumstátová (2000) porovnávala přímé a dvoustupňové tlumočení z hlediska množství zachované informace a $\mathrm{z}$ hlediska počtu a druhu chyb, jichž se tlumočníci dopustili.

Na Filozofické fakultě Univerzity Komenského v Bratislavě byla v letošním roce (2019) obhájena disertační práce M. Daniškové, zabývající se pilotáží (a retourem) v rámci procesu výuky tlumočení na Slovensku.

Průzkum mezi tlumočníky v evropských institucích a na českém trhu a následně mezi poslanci Evropského parlamentu, zaměřený na pilotáž a na retour, provedla Čeňková (2007). Ve vztahu k pilotáži se zaměřovala zejména na kritéria pro kvalitní pilotáž a na hlavní rozdíly v projevu tlumočníka, který ví, že jeho projev slouží jako projev pilotní (tedy na tzv. dvojí odpovědnost pilotního tlumočníka), v porovnání s tlumočníkem, který pilotáž (vědomě) neprovádí.

Závěry o spolehlivosti tohoto typu tlumočení $\mathrm{z}$ hlediska kvality přenosu informace a komfortu tlumočníka i př́ijemce tlumočení jsou nejednoznačné. Seleskovitchová (1995: 176) hovoří o mimořádné odpovědnosti tlumočníka zajištujícího pilotáž, na němž závisí jak jeho posluchači, tak kolegové přebírající jeho projev, a o riziku neodpovídající formy a nekoherentního obsahu. Toto riziko je naopak vyváženo skutečností, že „pivot [...] objasňuje cokoli, co mohlo být v originálu nejasné“. Obdobně Mikkelsonová o pilotáži tvrdí, že je „zjevně mnohem těžkopádnější než přímé tlumočení, a to i pokud probíhá simultánně“, avšak zároveň uvádí, že „zkušení konferenční tlumočníci jsou na tlumočení s pilotáží zvyklí, a [...] delegáti si většinou nejsou vědomi, že projev, který poslouchají, není tlumočen přímo z originálu, nýbrž z některé jiné kabiny“. Shlesingerová (2010: 276) o pilotáži uvádí, že se sice jedná o „druhé nejlepší řešeni“, avšak následkem změn v současném světě jde zároveň o stále rozšířenější formu tlumočení. Dále Shlesingerová (tamtéž) zmiňuje skutečnost, že „Mackintoshová (1983) nezjistila žádné významné rozdíly $\mathrm{v}$ informační ztrátě při přímém tlumočením a při pilotáži, ačkoli častěji docházelo k vynechání či zkreslení některých položek, např. čísel“.

Z výše uvedeného vyplývá, že názory na pilotáž zejména ve vztahu ke kvalitě tlumočení nejsou zcela jednoznačné, domníváme se však, že vzhledem k výše uvedenému nelze vliv dvoufázového převodu na kvalitu tlumočení vyloučit. 


\section{Retour}

Jak uvádí Bartolomiejczyková (2004: 239), „od počátků tlumočnického výzkumu panovalo mezi většinou autorů přesvědčení, že tlumočení ve směru B-A je ,nadřazeno ostatním; toto přesvědčení zacházelo často tak daleko, že uvedený směr býval považován za jediný přijatelný, $\mathrm{s}$ výjimkou ideální kombinace $\mathrm{A}-\mathrm{A}^{\text {“. }} \mathrm{V}$ současné době toto přesvědčení, typické zejména pro západoevropské tlumočnické „školy“, zdaleka neplatí výhradně. Pro tlumočníky takzvaných „malých jazykü“ je retour běžnou (a nezbytnou) praxí, a to zejména na domácím trhu; totéž platí i pro evropské instituce (ačkoli v současné době, kdy se i malé jazyky stávají pracovními jazyky C tlumočníků, jejichž mateřštinou je některý ze „starých“ jazyků EU, se potřeba retouru stává v evropských institucích méně naléhavou - viz Čeňková 2007). Tento vývoj nicméně vedl k obecnému uznání potřeby tlumočení do jazyka B provádět a začlenit jej do tlumočnických výcvikových programů.

Odpůrci retouru tvrdí, že tlumočení do nemateřského jazyka nemůže být z formálního hlediska (př́zvuk, jazyková správnost, stylistika, bohatost a přesnost vyjádření) stejně kvalitní jako tlumočení do mateřštiny. Jeho příznivci oproti tomu argumentují dokonalejším porozuměním textu $\mathrm{v}$ jazyce $\mathrm{A}$, které přispívá $\mathrm{k}$ vyšší míře zachování obsahu. I Seleskovitchová a Ledererová (1995: 177), striktně prosazující jako ideální kombinaci B-A, uvádějí, že je-li nutno volit mezi obsahem a formou, obsah je vždy prioritou. Preference nejen tlumočníků, nýbrž také př́ijemců tlumočení (poslanci Evropského parlamentu) zkoumala např́klad Čeňková (2007), která zjistila, že většina respondentů preferuje poslech tlumočení do jazyka $\mathrm{A}$. Závěry svého výzkumu porovnává Čeňková s Donovanovou (2002), která ve svém průzkumu v rámci OECD naopak dochází k závěru, že respondenti si rozdílů při různých směrech tlumočení nejsou vědomi. Tuto nejednotnost závěrů lze vysvětlit Gilovým (2005) tvrzením, že vliv směru tlumočení na přenos informace závisí na mnoha proměnných - na režimu tlumočení (simultánní vs. konsekutivní), na jazykové kombinaci, na tématu, situačním kontextu apod. a na různých kombinacích těchto faktorů.

\section{Hodnocení kvality}

Kvalita v tlumočení je pojem relativní. Jak uvádí Ďoubalová (2019: 21), „neexistuje všeobecně přijímané vymezení pojmu kvality (v) tlumočení. Ani pokusy nejpovolanějších odborníků (Gile, Moser-Mercerová a další) o obecnou definici nejsou zcela uspokojivé a nedokážou pojmout šiři jevů, které můžeme pod pojem kvalita subsumovat, faktorů, které kvalitu ovlivňují, a úhlů pohledu, které můžeme při posuzování kvality

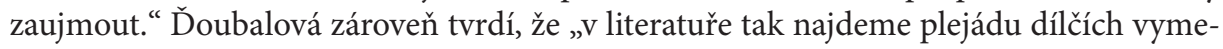
zení kvality v závislosti na zaměření dané výzkumné práce“. Kromè perspektivy výzkumu lze dle Shlesingerové (1997: 126) na kvalitu tlumočení nahlížet z perspektivy trhu, tj. potřeb a očekávání klienta, či z hlediska didaktiky (jaké aspekty tlumočení by měly být při výuce zdůrazňovány, jak efektivněji vyučovat dovednosti potřebné pro zajištění kvalitního tlumočení).

Pokud jde o hodnocení kvality, zaměřuje se Shlesingerová (1997: 128) na následující tři úrovně: intratextuální, intertextuální a instrumentální. Intratextuální rovina se vztahuje 
k cílovému textu samotnému jako produktu na základě jeho akustických, lingvistických a logických rysů. Hodnocení $z$ intertextuálního hlediska spočívá v porovnání zdrojového a cílového textu, jeho podobnostech a rozdílech. Instrumentální rovina pak představuje hledisko služby zákazníkovi, tedy použitelnost a srozumitelnost textu (je-li např́klad cílový projev př́liš rychlý, nedosahuje potřebné úrovně instrumentální kvality, protože brání porozumění). Ďoubalová (2019: 36) uvádí jako př́íklady kritérí intratextuální kvality logickou koherenci textu, správné použití jazykových a stylistických prostředků a terminologii apod. Intertextuální kvalitou rozumí např́íklad obsahovou přesnost, věrné převedení smyslu, úplnost, shodu či adekvátnost stylistických a jazykových prostř̌edků. Koncept instrumentální roviny je podle Ďoubalové dynamický a vystihuje tlumočnickou interakci a úspěšnost komunikace. Jak Ďoubalová zdůrazňuje, všechny tř̀i úrovně spolu úzce souvisejí.

I pro účely našeho výzkumu je nutno kritéria kvality vymezit. Za výchozí považujeme minimální standard kvality tlumočení, jímž je dle Hynkové Dingové (2017: 100) „Zachování věrnosti obsahu zdrojového sdělení včetně adekvátního stylu a jeho pragmatického smyslu podmíněného situačním kontextem - kritérium ekvivalentního účinku“. Tato definice podle našeho názoru pokrývá všechny tři výše uvedené roviny - intratextuální, intertextuální i instrumentální. Vzhledem k tomu, že v rámci našeho výzkumu se zaměřujeme na významové posuny a ztrátu informace ve sdělení $v$ cílovém jazyce (a jejich pravděpodobné příciny), tedy na obsahovou věrnost, bude převládat pohled intertextuální, s přesahem do roviny instrumentální (míra zachování informace umožňující porozumění textu). Jako relevantní faktory ovlivňující kvalitu při dvoufázovém tlumočení budeme zkoumat zejména povahu zdrojového projevu v první fázi a kvalitu pilotáže ve fázi druhé, v níž navíc tlumočníci tlumočí do jazyka B. Za významný faktor ovlivňující kvalitu tlumočení dále považujeme délku tlumočnické praxe jednotlivých tlumočníků.

Při hodnocení budeme vycházet z Cokelyho (1986) taxonomie ${ }^{9}$ tlumočnických chyb či posunů - omise, adice, substituce, intruze, anomálie - a jejich podkategorií.

Inspirovat se přitom budeme Napierovou (2002) a její dichotomií vědomého a nevědomého (a dále záměrného a nezáměrného) vynechání informace jako lingvistické tlumočnické strategie, kterou rozšíríme i na adice a substituce (právě strategičnost určitých voleb tlumočnických řešení posouvá hodnocení spíše statického produktu k výše uvedené dynamiččěǰ̌í, instrumentální rovině, k rovině užitečnosti textu pro posluchače).

\section{Hypotéza}

Vzhledem k povaze a způsobu existence zdrojového jazyka se domníváme, že bude-li při tlumočení mezi českým znakovým a anglickým mluveným jazykem docházet k významovým posunům a informačním ztrátám, budou odlišné od posunů a ztrát, $\mathrm{k}$ nimž dochází při tlumočení výhradně mezi mluvenými jazyky. Tato hypotéza bude ověřena za pomoci experimentu, $v$ jehož rámci bude zkoumáno tlumočení s pilotáží ve

9 Viz Hynková-Dingová (2017: 109). 
dvou jazykových kombinacích: český znakový jazyk - mluvená angličtina a mluvená francouzština - mluvená angličtina. V obou př́padech bude pilotním jazykem čeština. ${ }^{10}$

\section{Výzkumné otázky}

V souvislosti s výše uvedenou hypotézou si klademe následující výzkumné otázky:

- Liší se výskyt a typy významových posunů a informační ztráty při tlumočení mezi jazyky se stejnou a různou modalitou? Pokud ano, je tato odlišnost dána modalitou jednotlivých jazyků (vizuálně-motorický vs. audio-orální) či jinými faktory?

- Pokud tlumočení mezi příslušnými jazyky probíhá prostřednictvím pilotáže, je jedním z faktorů ovlivňujících významové posuny a informační ztrátu právě pilotáž?

- Pokud dochází k posunům a ztrátám, děje se tak v první, nebo ve druhé fázi? ${ }^{11}$

- Jaké faktory zpo̊sobují tyto posuny a ztráty v těchto fázích tlumočnického procesu?

- Je jedním z faktorů významových posunů a informační ztráty skutečnost, že ve druhé fázi provádějí tlumočníci retour?

- Je výskyt významových posunů a informační ztráty ovlivněn délkou tlumočnické praxe?

\section{Metoda výzkumu}

Odpovědi na tyto otázky se snažíme nalézt prostřednictvím experimentu prováděného v laboratorních podmínkách, spočívajícího v přetlumočení identického zdrojového textu sepsaného v češtině a předneseného v ČZJ a ve francouzštině. Pro účely překladu textu a případných konzultací významových posunů a ztrát byli zvoleni bilingvní mluvčí (ČZJ-ČJ, FR-ČJ). Původní projevy budou tlumočeny vždy čtyřmi tlumočníky do češtiny jako pilotního jazyka, přičemž z každého jednoho pilotního tlumočníka bude tlumočit vždy jeden tlumočník do mluvené angličtiny.

Tlumočníci budou do jednotlivých dvojic (zdrojový jazyk - pilotní jazyk a pilotní jazyk - cílový jazyk) rozděleni podle délky praxe (delší praxe - DP, kratší praxe - KP) tak, aby byly pokryty všechny možné kombinace, tj. DP-DP, DP-KP, KP-DP a KP-KP. Tímto způsobem bude možné zjistit, zda se posuny vyskytují již v pilotním, nebo až v cílovém projevu, a zda existuje vztah mezi významovými posuny a délkou tlumočnické praxe.

Analýza první fáze tlumočení se bude zaměřovat především na faktory a projevy specifické pro modalitu jazyků každé kombinace, druhá fáze se bude zaměřovat na faktory a projevy specifické pro tlumočení do cizího jazyka (retour), přičemž bude brána v úvahu i kvalita pilotáže jako vstupu pro tlumočníky tlumočící do angličtiny.

$10 \mathrm{~V}$ dalších fázích zkoumání by bylo žádoucí porovnat tlumočení s pilotáží s tlumočením prrímým, z důvodu nízkého počtu kvalifikovaných tlumočníků kombinace CZJ-AJ by však nebyla zajištěna homogennost, a tedy reprezentativnost zkoumaných vzorků.

11 První fází tlumočení rozumíme převod z českého znakového/francouzského mluveného jazyka do českého mluveného jazyka, druhou fází pak převod z českého mluveného jazyka do anglického mluveného jazyka. 
Po analýze jednotlivých výkonů budou následovat dotazníková šetření/rozhovory s tlumočníky, jejichž prostřednictvím bude mimo jiné zjištováno, jak tlumočníci hodnotí konkrétní tlumočnickou situaci a zda byla příslušná tlumočnická řešení nevědomá či vědomá, nezáměrná či záměrná, a tedy strategická.

Závěry budou sloužit jako podklad k úvaze o stávající praxi i vzdělávání tlumočníků zejména v oblasti tlumočení mezi znakovými a mluvenými cizími jazyky.

\section{BIBLIOGRAFIE}

Bartolomiejczyk, Magdalena (2004) 'Simultaneous Interpreting A-B vs. B-A from the interpreters' standpoint', in Gyde Hansen - Kirsten Malmkjær - Daniel Gile, Claims, changes, and challenges in translation studies: selected contributions from the EST Congress, Copenhagen 2001, Philadelphia: J. Benjamins Pub., 239-249.

Čeňková, Ivana (2007) 'Retour a pilotáž: každodenní realita pro tlumočníky v Evropských institucích', in Juraj Dolník - Zuzana Bohušová - Anita Hutková, Translatológia a jej súvislosti. 2, Banská Bystrica: Univerzita Mateja Bela, 97-112.

Danišková, Miroslava (2019) Retour a pilotáž v rámci procesu výučby tlmočenia na Slovensku, Bratislava: Univerzita Komenského v Bratislave, vedoucí práce prof. PhDr. Mária Kusá, CSc.

Ďoubalová, Jana (2019) Kvalita z hlediska tlumočení jako strategického rozhodovacího procesu - direkcionalita a strategie při tlumočení právních textů, Praha: Univerzita Karlova, vedoucí práce prof. PhDr. Ivana Čeňková, CSc.

Hynková Dingová, Nada (2017) Typologie chyb v tlumočení z češtiny do českého znakového jazyka. Praha: Univerzita Karlova, vedoucí práce prof. PhDr. Alena Macurová, CSc.

Gile, Daniel (2005) 'Directionality in conference interpreting: a cognitive view. Université Lumière Lyon 2', in Rita Godijns - Michaël Hindedael (eds.) Directionality in interpreting. The 'Retour' or the Native?, Ghent: Communication and Cognition, 9-26.

Jarolím, Viktor (1999) Tlumočení s pilotáží, Praha: Univerzita Karlova, vedoucí práce PhDr. Jana Rejšková.

Kumstátová, Věra (2000) Tlumočení s pilotáží, Praha: Univerzita Karlova, vedoucí práce prof. PhDr. Ivana Čeňková, CSc.

Llewellyn-Jones, Peter (2015) 'Target language styles and source language processing in conference sign language interpreting', in The Sign Language Interpreting Studies Reader, Amsterdam: John Benjamins, $128-144$.

Mikkelson, Holly (1999) 'Relay Interpreting: A Solution for Languages of Limited Diffusion?', The Translator 5(2): 361-380.

Napier, Jemina (2002) Sign language interpreting. Linguistic coping strategies. Coleford: Douglas McLean Publisher.

Pfau, Roland - Schermer, Trude (2016) 'Psycholinguistics', in Anne Baker The Linguistics of Sign Languages, Amsterdam/Philadelphia: John Benjamins Publishing Company, 25-50.

Pöchhacker, Franz (2004) Introducing Interpreting Studies. London/New York: Routledge.

Seleskovitch, Danica - Lederer, Marianne (1995) A systematic approach to teaching interpretation, The Registry of Interpreters for the Deaf.

Shlesinger, Miriam (1997) 'Conference Interpreting: Current trends in research', in Proceedings of the International Conference on Interpreting: What do we know and how?, Amsterdam/Philadelphia: Benjamins Translation Library, 123-131.

Slánská Bímová, Petra - Okrouhlíková, Lenka (2008) Rysy přirozených jazyků. Znakový jazyk jako přirozený jazyk. Lexikografie. Slovníky českého znakového jazyka, Praha: Česká komora tlumočníků znakového jazyka. 


\title{
RÉSUMÉ
}

Interprétation de conférence entre la langue de signes tchèque et l'anglais parlé

L'interaction de la communauté sourde avec celle des entendants au niveau international devenant de plus en plus fréquente, la langue de signes (tchèque) entre en contact avec des langues parlées étrangères (surtout l'anglais), ce qui crée un besoin d'interprétation - soit en relais (en passant par une troisième langue), soit directement.

C'est justement le relais qui constitue le thème central de notre recherche. Bien que son impact négatif sur la qualité d'interprétation n'ait pas été prouvé, nous croyons que l'interprétation en deux phases peut exercer une certaine influence sur l'interprétation, notamment en ce qui concerne la fidelité informationnelle, et que les glissements de sens et pertes d'information potentielles différeront en fonction de la modalité de la langue (visuelle et gestuelle $\mathrm{X}$ audio-orale).

Cette hypothèse sera testée par une expérience réalisée dans des conditions de laboratoire. Un discours identique sera prononcé par un orateur de langue maternelle française et par un orateur dont la langue maternelle est la langue de signes tchèque ; les discours seront traduits vers l'anglais parlé par l'intermédiaire du tchèque, chacun par quatres paires d'interprètes.

Le produit sera analysé en utilisant la typologie des méprises d'interprète de Cokely (1986): omissions, ajouts, substitutions, interférences, anomalies.

L'objectif de cette analyse est de déterminer si l'interprétation en relais du discours prononcé en langue de signes tchèque vers l'anglais parlé diffère de façon significative de l'interprétation en relais vers l'anglais parlé du même discours prononcé en français parlé, et dans quelle phase de l'interprétation se produisent ces déviations potentielles, à savoir si elles sont dues aux différences dans la nature des deux langues (codes) de départ, ou bien au fait que les interprètes travaillant vers l'anglais font un retour, c'est-à-dire une interprétation vers leur langue $\mathrm{B}$, et si la qualité de leur performance dépend de leur niveau d'expérience professionnelle.

Les résultats de l'expérience ne seront probablement que de nature descriptive, bien que déventuelles conclusions prescriptives, relatives à la pratique et surtout à l'enseignement de l'interprétation, ne soient pas à exclure.

\author{
Mgr. Marie Přibylová \\ Ustav translatologie, Filozofická fakulta, Univerzita Karlova \\ mariepribylova@seznam.cz
}

